\title{
Elusive flowering signal pruned of mystery at last
}

Last week, two papers in Science reported the discovery of florigen, a long-sought compound with the power to make flowers bloom. But if the celebration of its discovery seems a little muted, it is because many researchers have heard this claim before. And this time, the reports come as an old one is retracted amid charges of data manipulation.

The discovery of florigen was heralded in 2005, when another Science paper ${ }^{1}$ claimed that it was the RNA produced by a gene called FLOWERING LOCUS T, or FT. But now the authors of that paper have retracted their findings, and in its stead come two papers that say florigen is not FT RNA, but the protein produced by the FT gene.

The finding could solve a riddle that has been around since 1865, when German botanist Julius von Sachs observed that illuminating a single leaf on a darkened morning-glory plant was enough to prompt the plant to bloom. That suggested that a signal travelled from the leaf to the site of flower initiation. Some 70 years later, the signal was christened florigen by the Russian plant physiologist Mikhail Chailakhyan.

The hunt was on, and physiologists spent decades testing compounds extracted from flowering plants, only to fail to find the compound responsible. Over time, the florigen concept fell out of fashion, giving way to a hypothesis that the flowering signal was not a dedicated compound but rather a complex mix of nutrient and hormonal signals. "For a long time, florigen was the f-word," says Joe Colasanti, a plant biologist at the University of Guelph in Ontario, Canada. "You didn't want to bring it up."

But the recent work shows that researchers were looking in the wrong places over all those years, says Jan Zeevaart, an emeritus plant biologist at Michigan State University in East Lansing. Most people expected florigen to be a small chemical compound. "They weren't looking for proteins," he says.

Then, in August 2005, two papers reported that although the FT gene produces RNA in the leaf, the encoded protein acts in the tip of the shoot, where flowers form. The simplest explanation was that a product of FT - either the RNA or the protein - somehow travelled from the leaf to the shoot tip. Within a month, a team led by Ove Nilsson of the Swedish University of Agricultural Sciences in Umeå announced that this product was FT RNA. Although that didn't rule out the possibility that the FT protein also

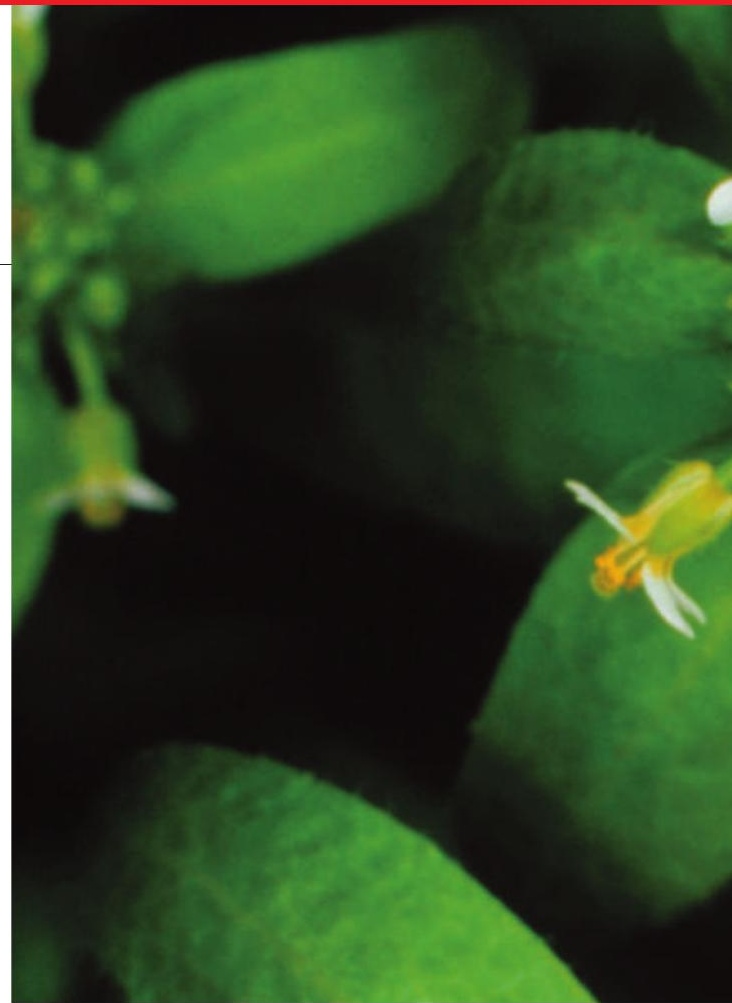

travelled from leaf to shoot, it suggested that FT RNA was at least a component of florigen. The discovery was significant enough to make Science's list of 'Breakthroughs of the Year'.

But now Nilsson has retracted the paper and has accused Tao Huang, the paper's first author, of manipulating data. Nilsson says Huang selectively excluded some data points and statistically overweighted others. Huang, who left Nilsson's lab for a faculty position at Xiamen University in China after the paper was published, maintains that excluding the data was justifiable. He says he circulated the data - with excluded data points marked - to

\section{Brain's speech site is revisited and revised}

Analysis of two damaged brains, preserved in a museum since the nineteenth century, could force neuroscientists to rethink the area where language resides in the brain.

In 1861, the French surgeon and anatomist Paul Broca described two patients who had lost the ability to speak. One patient, Lelong, could produce only five words, and the second, Leborgne, could utter only one sound - "tan". After their deaths, Broca examined their brains and noticed that both had damage to a region in the frontal area on the left side.

Broca's area, as it became known, is now thought to be the brain's speech-processing centre.
Broca kept the patients' brains for posterity, preserving them in alcohol and placing them in a Paris museum. And that's where Nina Dronkers, of the VA Northern California Health Care System in Martinez, and her colleagues picked them up, in order to reinspect the damage using magnetic resonance imaging.

Leborgne's brain had been scanned twice before, but not Lelong's. And neither had been compared with modern interpretations of Broca's area. After the team put the two brains through a scanner, they came up with a surprising finding: in both patients, the damaged

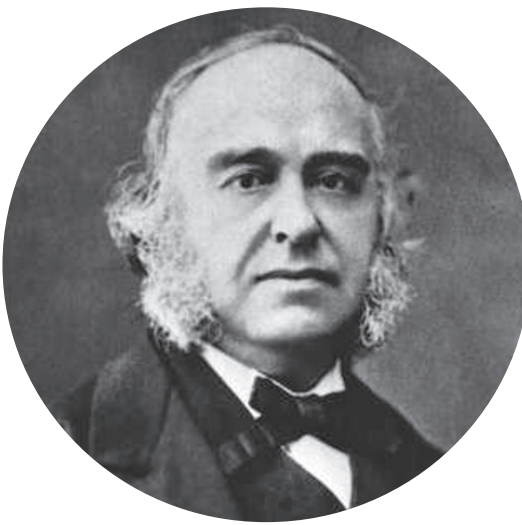

Paul Broca: discovered a region of the brain responsible for language.

area was much larger than the region that is now considered to be Broca's area.
"We were noticing that what people were calling Broca's area encompassed large areas of the frontal lobe," says Dronkers. The scans show that neither of the old brains had damage that affected the whole region now known as Broca's area. But damage also stretched far into other regions beyond this spot.

Broca realized this at the time, says Dronkers, and noted that the areas of damage were different in the two patients. But his conception of the area involved in speech processing has become simplified by others over time, the authors argue. They published their findings online earlier this 
